\title{
RELATIONSHIP BETWEEN PRICE WITH PATIENT SATISFACTION IN HOSPITAL BHAKTI MEDICARE, CICURUG, REGENCY OF SUKABUMI
}

\author{
Hasrul $^{1)}$ \\ ${ }^{1)}$ Universitas Pakuan, Bogor, Indonesia \\ Corresponding Author: hasrul@unpak.ac.id
}

\begin{abstract}
The purpose of this study is to determine the presence or absence of prince relationships with patient satisfaction in hospitals Bhakti Medicare, Cicurug, Sukabumi. The population of this research are Bhakti Medicare hospital patient, Cicurug, Sukabumi consisting of jasmine room patient, rose room, dahlia room and orchid room with a population of 130 patiens where to get the minimum sample amount used slovin's formula. After the calculation obtained by the sample of 100 repondents. The collected data is then processed using simple correlation and multiple correlation techniques using SPSS (statistical Package for social science) software. Result of research : There is positive relation between price with correlation coefficient value equal to $\left(\mathrm{r}_{\mathrm{y} .1}\right)=0.679$ included in strong relationship category. While Price contribution to patient satisfaction equal to $\mathrm{r}^{2}=\left(\mathrm{r}_{\mathrm{y} .1}\right)^{2}=46,2 \%$. The results of the international study provide some implications with the results of the hypothesis obtained include: proce contribution is considered strong against patient satisfaction which means increased price will ensure patient satisfaction in Bhati Medicare hospital, Cicurig, Sukabumi regency. The results of the international study provide that price hace trong relation with costomer satisfaction equal to $(r)=0.348$ units. In the most important dimension proce variable the relationship is the dimension of "patment period" $\left(\mathrm{X}_{14}\right)$ which has the strongest relationship with "consistency" dimension $\left(\mathrm{Y}_{3}\right)$ on patient satisfaction variable with correlation coefficient 0,641 (strong relation). Thus it can be concluded that the price dimension that most determine patient satisfaction at Bhakti Medicare Hospotal, Cicurug, Sukabumi Regency is the dimension of price.
\end{abstract}

Keywords: price, patient satisfaction and payment period..

\section{INTRODUCTION}

located in District Cicurug, Sukabumi District, exactly Jl. Raya Siliwangi No.186 B Cicurugsukabumi. Bhakti Medicare Hospital is engaged in health care, with the motto: "serve wholeheartedly", thus patient satisfaction is one of the goals. The following is the number of patient visits, both inpatient and outpatient at Bhakti Medicare Hospital [1].

The data shows that Bhakti Medicare Hospital patients begin to decrease in 2012 to 2014 as many as 1,130 patients or $7.9 \%$ while at the same time $(12 / 08 / 2015)$ there is a very significant increase of patient at Syamsudin General Hospital, Sukabumi 12.00 patient. $^{1}$

The visit target shows that the number of patients treated at Bhakti Medicare Hospital is still below the target of $66 \%$ of the target that management is charged while the number of patients using the remedy service decreased by $4 \%$.

Even complaint data shows an increase in the period of 2013 and 2014 which assumed that the decrease of the quality of service to Bhakti Medicare Hospital is increased by $2 \%$.

From the above data it is assumed that this decrease is due to changes in the level of satisfaction with the hospital.
Initial testing can be obtained data as much as $42 \%$ of patients are not satisfied using Bhakti Medicare hospital services as a means for healing and treatment and maintain good relations with the hospital. As many as $33 \%$ of patients do not always buy drugs from hospital pharmacies. As many as $35 \%$ of patients did not perform routine checks every month and $38 \%$ did not recommend Bhakti Medicare hospital to handle health to relatives and friends.

\section{Formulation of the problem}

The problem formulation in this research is whether there is relation of price with patient satisfaction at Bhakti Medicare Hospital, Cicurug, Sukabumi Regency.

\section{Research purposes}

The purpose of this study is to answer the research problem whether there is a relationship between the price with the level of patient satisfaction.

\section{Customer satisfaction}

Satisfaction of Customer is the result of accumulation from consumer or customer in using product or service. (Handi Irawan [2].

Zeithaml, V, A \& Bitner, M, J \& Gremler, D define that Service quality, the customer's perception of 
the service component of a product, is also a critical determinant of customer satisfaction. Service quality is the customer perception of the service component of a product, and also an important determinant in achieving customer satisfaction [3]. Indicators of qualitative services are: 1) reliability; 2) Responsiveness; 3) Assurance; 4) Empathy and 5) Physical Evidence.

\section{Price}

Price is a sum of money to be paid by a customer or an exchange to receive goods or services. (P. Baines, C. Fill, and K. Page [4])

Tjiptono, states that the price is a monetary unit or other measure (including other goods and services) which is derived in order to obtain the right to buy or use of a good or service [5]. And indicators of the price are: 1) List of prices; 2) Discounts; 3) Payment Period.

\section{Relevant Research Results}

Relevant earlier research results are used to illustrate the position and feasibility of the study of the relationship between price and patient satisfaction.

\section{International Journal}

Table 1. Coefficient for Proce and costumer statisfaction

\begin{tabular}{|c|c|c|c|c|c|}
\hline \multirow[t]{2}{*}{ Model } & \multicolumn{2}{|c|}{ Unstandardized Coefficients } & \multirow{2}{*}{$\begin{array}{l}\text { Standardized } \\
\text { Coefficients } \\
\text { Beta }\end{array}$} & \multirow[t]{2}{*}{$\mathrm{t}$} & \multirow[t]{2}{*}{ Sig } \\
\hline & B & Std. Error & & & \\
\hline (Constant) & 2.251 & .248 & & 10.174 & .000 \\
\hline Price & .352 & .071 & .348 & 4.936 & .000 \\
\hline
\end{tabular}

Arslan Umar, Rohaizat Bahrun, Inda Sukati from Faculty of Management, Malaysia Technology University, 81310 Skudai, Johor, Malaysia in his journal entitled Costumer Satisfaction as mediator between price, trust and Brand loyalty: A case study form Malaysia [6] in "Price is significant predicting costumer satisfaction with 0.348 units change per one unit change in price" Table 1 shows the relationship between price $(\mathrm{X})$ and customer satisfaction $(\mathrm{Y})$. Price significantly predict customer satisfaction with 0.348 units changed per one unit price change so assumed price is closely related to patient satisfaction.

National Journal

Lily Harjatin dan Yurike Venesia with research titles Influence Quality of Service and Prices Against Customer Satisfaction At Air Tiger Airlines Mandala. The purpose of this research is to know: (1) Quality of Service of Tiger Air Mandala, (2) Customer Price at Tiger Air Mandala, (3) Satisfaction of Tiger Air Mandala Customer, (4) Influence Quality of Service and Price to Tiger Air Mandala Customer Satisfaction. By using judgment sampling method with respondent people who have used Tiger Air Mandala flight service. Given the existence. Result of research 1) Test result with SPSS obtained for variable X1 (Quality of service) obtained nilat $\mathrm{t}$ arithmetic $=3,980$ with significance level 0,000 . Using the 0.05 significance limit, the significance value is less than the 5\% level. 2 ) the results of testing with SPSS obtained for the variable $\mathrm{X} 2$ (Price) obtained $\mathrm{t}$ value $=5,150$ with a significance level of 0.05 , the value of significance is smaller than the level of $5 \%$, which means Ho is rejected and $\mathrm{Ha}$ accepted. Thus, the second hypothesis is accepted. 3) The value of $\mathrm{R}$ shows a number of 0.744 which means Quality of Service and price has a positive relationship with Customer Satisfaction. While the value of adjusted $\mathrm{R}$ square shows the number of 0.545, which means $54.5 \%$ variable Satisfaction penlanggan can be explained By Variable Service and Price Quality and the remaining $45.5 \%$ explained by other factors [7].

Indah Artiningtyas. The Influence of Quality of Service, Price and Trust on Customer Satisfaction (Case Study On Tire Retreader Store Top Cool Semarang). The purpose of research to analyze the influence of service quality, price and trust to customer satisfaction at Tire Retreader Store Top Cool Semarang. The sample in this study were 97 respondents. The sampling technique used in this research is purposive sampling, the sampling is based on the criteria, the consumers who use the products and services at the Tire Retreader Store Top Cool Semarang has been 2 times and willing to be the respondent when the questionnaire is distributed. The results showed that the equation of double linear or standardized coefficients obtained: $\mathrm{Y}=0.218 \mathrm{X},+$ $0.325 \mathrm{X}_{2}+0.309 \mathrm{X}_{3}+\mathrm{e}$. From the equation shows that the price is more positive effect on customer satisfaction with regression coefficient of 0.325 ; then the trust also has a positive effect on customer satisfaction with regression coefficient of 0.309 and service quality have a positive influence on customer satisfaction with regression coefficient of 0.218 [8]

\section{Research Framework}

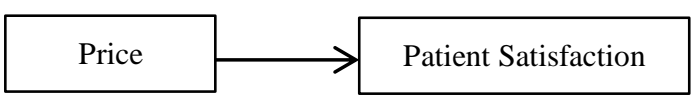

Figure 1. Framework

Based on the above research framework can be proposed research hypothesis is, the price is closely related to patient satisfaction.

\section{RESEARCH METHODS}

The research method used is survey method, with correlation approach, that is research method designed to get information about the relationship between different variables in one population. The object of this research is price as independent variable that is price $(\mathrm{X})$ to dependent variable that is patient 
satisfaction level $(\mathrm{Y})$ by using product moment correlation technique.

\section{Population}

The research results are Bhakti Medicare Hospital, Cicurug, Sukabumi District which is patient in jasmine room, rose room, dahlia room and orchid room as many as 130 patients with 100 respondents.

\section{Sampling technique}

Sampling technique using judgment sampling technique or purposive sampling that is sampling is done based on consideration which is appropriate with research purpose.

\section{Data Collection Technique}

Data collection procedure is done by questionnaire that is data collection technique by giving a list of written questions to the respondents ie patients at Bhakti Medicare Hospital, Cicurug, Sukabumi District, questionnaire has been determined the contents and the material.

\section{Measurement of Research Variables}

The independent variables (price) and the dependent variable (tingkan satisfaction) which is the interval scale are measured using Likert scale (Indriantoro and Supomo, 2002) with score numbers 1 to 5 .

\section{Data Analysis Method}

The quality of data on qualitative data used in this study used validity test, normality test (One Sample Kolmogorov smirnov), homogeneity test of variance (bartlet) and linearity test, calculation of test was done using SPSS software aid. Validity test using product moment correlation formula from Karl Pearson, while reliability test using Cronbach Alpha formula.

\section{Hypothesis Testing}

To test the hypothesis criteria accepted or rejected, then tested the classical assumption that is simple correlation test of product moment from Karl Pearson to test the strength of correlation variable $X$ (independent) with variable $Y$ (dependent).

\section{Dimension Analysis}

Dimensional analysis is used to find out the relationship between the dimensions of the independent variables with the dimensions of the dependent variable. Dimensional analysis is done by making dimension correlation matrix between variables.

\section{RESULTS AND DISCUSSION}

1. Description of Data Statistics Variable Bound Satisfaction of patient (Y)
Table 1. Description of Data Statistics Variable Bound Satisfaction of patient (Y)

Patient Satisfaction
\begin{tabular}{|l|r|}
\hline N Valid & 100 \\
Missing & 0 \\
Mean & 143.8400 \\
Median & 143.5000 \\
Mode & 138.00 \\
Std. Deviation & 13.29291 \\
Variance & 176.701 \\
Range & 113.00 \\
Minimum & 60.00 \\
Maximum & 173.00 \\
Sum & 14384.00 \\
\hline
\end{tabular}

Based on the results of the research that has been collected authors on the variable satisfaction of patients with 35 valid questions, obtained the lowest emperical score is 60 and the highest 173 with a range score of 113.

Summarized data as shown in the description of data, as follows:

The mean values for the patient satisfaction variables were 143.84 , the median of 143.50 , the mode of 138.00 , the standard deviation of 13.29 , the variance of patient satisfaction data indicated a value of 176,701 , with many interval classes 8 lowest frequency debgabs of $3 \%$ of respondents said patient satisfaction was at interval score $60-73$, highest relative frequency $29 \%$ of respondents stated patient satisfaction was at interval score 130 - 143 .

The patient's satisfaction questionnaire consists of 35 valid questions, the lowest theoretical score is 35 and the highest score is 175 , with theoretical median is $(35+175: 2) 105$, the lowest emperical score (research result) is 60 and the highest score is 173 , with median emperic $(60+173: 2) 116$ means high score, thus patient satisfaction included in high level category.

2. Description of Free Data Variable Statistical Price (X)

Table 2. Description of Free Data Variable Statistical Price (X)

\begin{tabular}{|l|r|}
\multicolumn{2}{c}{ Cost } \\
\hline N Valid $\quad$ Missing & 100 \\
Mean & 0 \\
Median & 150.9900 \\
Mode & 148.0000 \\
Std. Deviation & 148.00 \\
Variance & 15.99274 \\
Range & 255.768 \\
Minimum & 142.00 \\
Maximum & 43.00 \\
Sum & 185.00 \\
\hline
\end{tabular}


The lowest emperical score was 43 and highest 185 with score range 142, the result of data analysis obtained mean value for price variable 150,99 , median 148.00 mode equal to 148,00 , deviation standard equal to 15,99 , variance of price data show value at 255.76 , with many interval 8 classes with the lowest frequency of $1 \%$ of respondents saying prices are at the 43-60 frequency interval of the highest relative high $24 \%$ of respondents stated the price is at the interval score of 133-150. The price question consists of 37 valid questions, the lowest theoretical score is 37 and the highest score is 185 , with theoretical median being ( 37 + 185: 2) 111, the lowest empirical score (research result) is 43 and the highest score adalah 185, with an empirical median $(43+185: 2) 114$ means empirical scores move on high score areas, thus prices fall into high-level categories.

\section{Hypothesis Testing}

The relationship between price $(\mathrm{X})$ and patient satisfaction (Y)

Table1. Coefficient for Proce and costumer statisfaction

\begin{tabular}{lcclll}
\hline Model & Unstandardized Coefficients & $\begin{array}{l}\text { Standardized } t \\
\text { Coefficients }\end{array}$ & Sig \\
& B & Std. Error & Beta \\
\hline (Constant) & 58.581 & 9.354 & & 6.262 & .000 \\
Price & .565 & .062 & .679 & 9.165 & .000 \\
\hline
\end{tabular}

a. In accordance with the research hypothesis, then the relationship between price and patient satisfaction by using product moment correlation technique obtained correlation coefficient $r_{y \cdot 1}=0,679$. This shows a strong relationship between price variables and patient satisfaction variables.

b. Price contribution $(\mathrm{X})$ with patient satisfaction $(\mathrm{Y})$ is calculated based on the coefficient of determination is $r^{2}=\left(r_{y .1}\right)^{2}=0,462$, Means that the price varieabel contributed $46.2 \%$ to patient satisfaction (Y), the remaining 53.8\% (100\%$46.2 \%$ ) influenced by other variables.

c. Functional relationship between price and patient satisfaction can be seen in the equation :

\section{$\hat{\mathbf{Y}}=\mathbf{5 8 , 5 8 1 + 0 , 5 6 5 X}$}

The equation above shows that the price has a positive effect on customer satisfaction with regression coefficient of 0,565 which means patient satisfaction will increase 0,565 units if price variable (X) increases one unit with constant 58,581.

d. Result of linearity test show value of $\mathrm{F}$ test $=$ 130,484 reach significant level. e. To test the hypothesis that there is a positive relationship between variables $\mathrm{X}$ with $\mathrm{Y}$ required test significance correlation coefficient is with $t$ test.

$\mathrm{H}_{\mathrm{o}}=$ There is no positive relationship between price and patient satisfaction.

$\mathrm{H}_{\mathrm{o}}=$ There is a positive relationship between price and patient satisfaction.

Criteria testing significance correlation coefficient is if t-count> t-table. From table 24 coefficents obtained t-count $=9,165$, Sig level $=0,05$ dab N-1 or $100-1=99$ obtained t-table $=16,6604$. It turns out that the value of $t$-count> t-table or 9,165> 1,6604 , means price $(\mathrm{X})$ significant to patient satisfaction $(\mathrm{Y})$.

\section{Dimension analysis}

Dimensional analysis is used to determine the relationship between the dimensions on the independent variable with the dimensions of the dependent variable. Deimensi analysis is done by making dimension correlation matrix between variables. The result of dimension analysis is done by making dimension correlation matrix between variables. Dimension analysis results on the variables. The result of the dimension analysis on the research variables can be seen in the table below.

Table 3 dimension analysis

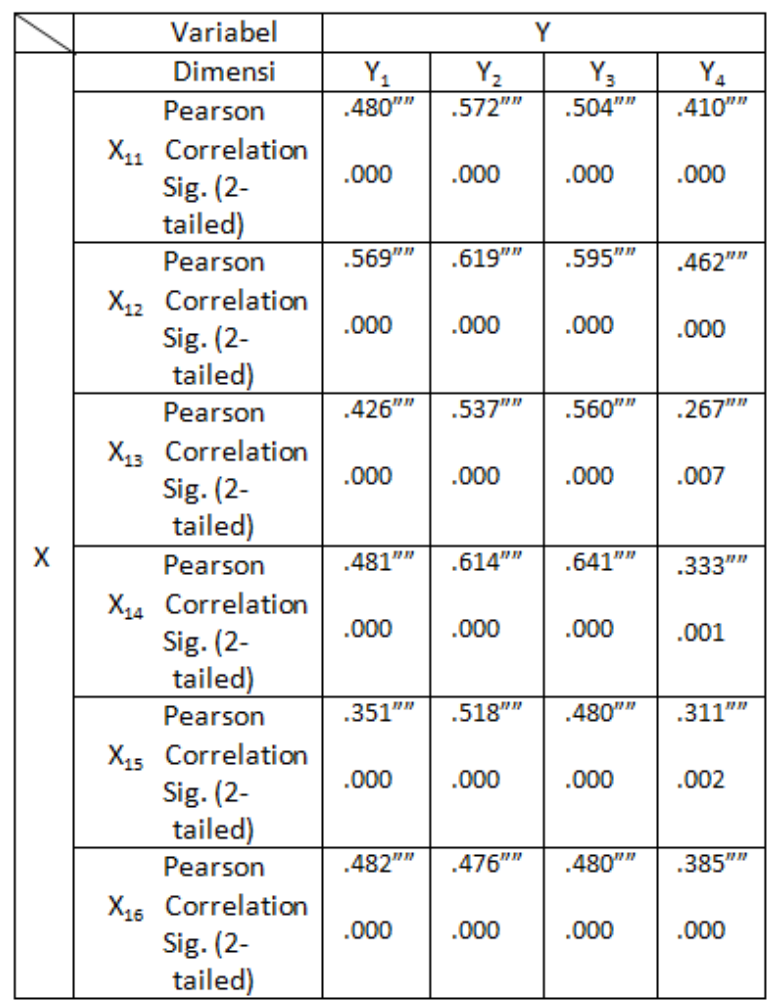




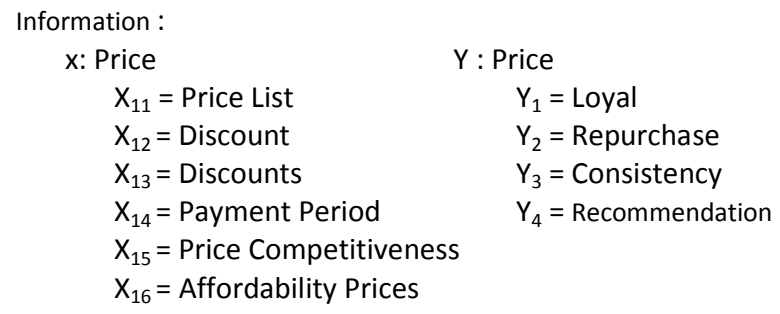

According to Sugiyono [9] correlations between dimensions can be interpreted, as follows:

Table 4. Level of Strenght

\begin{tabular}{|c|c|}
\hline $\begin{array}{c}\text { Correlation } \\
\text { Coefficient }\end{array}$ & Level of Relationship Strength \\
\hline $0,000-0,199$ & Very Weak \\
\hline $0,200-0,399$ & Weak \\
\hline $0.400-0,599$ & Medium \\
\hline $0,600-0,799$ & Strong \\
\hline $0,800-1,00$ & Very Stronng \\
\hline
\end{tabular}

At the Price Variable the most powerful dimension of the relationship is the dimension "payment period" $\left(\mathrm{X}_{14}\right)$ which has the strongest relationship with the dimension of "consistency" $\left(\mathrm{Y}_{3}\right)$ on patient satisfaction variable with correlation coefficient 0,641 (strong relation). Thus it can be concluded that the price dimension that most determine patient satisfaction at Bhakti Medicare Hospital, Cicurug, Sukabumi Regency is the price dimension.

\section{Discussion of Research Results}

Relationship between price $(\mathrm{X})$ with Patient Satisfaction (Y).

a. In accordance with the statistical hypothesis then the relationship between price $(\mathrm{X})$ with patient satisfaction (Y) by using product moment correlation technique obtained correlation coefficient $r_{y .1}=06,679$. The relationship is significant because $\mathrm{Sig}=0,000$ is identical to $\mathrm{p}$ value, where $\mathrm{p}$-value is less than $\alpha(0,05)$. Therefore $\mathrm{H}_{\mathrm{o}}$ rejected and $\mathrm{H}_{1}$ accepted, mean there is a positive and significant relationship between price $(X)$ and consumer satisfaction $(Y)$.

b. Price contribution $(\mathrm{X})$ with patient satisfaction $(\mathrm{Y})$ is calculated based on the coefficient of determination is $r^{2}=(r y .1)^{2}=0,462$. Means that price variable make contribution equal to $46,2 \%$ to patient satisfaction (Y).

c. Analysis of functional relationship between price and consumer satisfaction in Bhakti Medicare Hospital, Cicurug, Sukabumi Regency, the result of functional relation

\section{$\hat{\mathbf{Y}}=58,581+0,565 X 1$.}

This means that the value of constant (a) of 58,581 means that if the value of price (X) is constant or 0 , then the patient's satisfaction is 58.581 and the value of $b$ is 0.565 meaning that each increase of one unit of price $(X)$ means it will affect the patient satisfaction handling of $\mathbf{0 . 5 6 5}$ units.

d. The most powerful dimension of the relationship is the dimension "Payment period" $\left(\mathbf{X}_{14}\right)$ which has the strongest relationship with dimensions "consistency" $\left(\mathbf{Y}_{3}\right)$ on patient satisfaction variable with correlation coefficient 0,641 (strong relation). Thus it can be concluded that price dimension is the most determining variable of patient satisfaction at Bhakti Medicare Hospital, Cicurug, Sukabumi Regency.

\section{CONCLUSION}

1. There is a positive influence between price and patient satisfaction with coefficient value of 0.769 included in strong relationship category. While the contribution of price to satisfaction of patient equal to $46,2 \%$ so that customer satisfaction can be improved through pricing strategy carefully.

2. Variabel harga membentuk kontribusi sebesar $46.2 \%$ terhadap kepuasan pasien (Y).

3. Dimension "payment period" $\left(\mathrm{X}_{14}\right)$ which has the most close relationship with the dimension of "consistency" $\left(\mathrm{Y}_{3}\right)$ on patient satisfaction variable with correlation coefficient 0,641 (strong relation). Thus it can be concluded that the price dimension most determine patient satisfaction.

4. Functional relationship between price and patient satisfaction can be seen in the equation:

\section{$\hat{\mathbf{Y}}=\mathbf{5 8 , 5 8 1 + 0 , 5 6 5}$}

The equation above shows the price has a positive effect on customer satisfaction with regression coefficient of 0,565 which means patient satisfaction will increase 0.565 unit price variable (X) increases one unit with constant 58,581.

\section{Implications}

Customer ruling is a feeling of immediate pleasure that the customer feels when the customer's expectations of a product are met or even exceed customer expectations. When a customer feels satisfied then the customer can re-buy again even the customer will share the fun experience with their relatives for their satisfactory results after consuming the product.

Customer satisfaction has an important impact on the business continuity of Bhakti Medicare Hospital, Cicurug, Sukabumi Regency because it can create customer loyalty in the form of positive word of mouth and repurchase so that the number of customers will survive or increase which will ultimately maintain and increase the income and profit of Bhakti Hospital Medicare, Cicurug, Sukabumi District.

Customer Satisfaction can also improve the competitiveness of Bhakti Medicare Hospital, Cicurug, 
Sukabumi Regency fiber ready to compete. In addition to competitors from the area of Sukabumi District, there are also competitors from other areas Sukabumi District As Sukabumi and Bogor City which also increased pertumbehan the construction of his hospital.

Based on the conclusions of this study customer satisfaction can be improved through the dimension of "payment period" which includes advance payment, settlement, payment due and payment period and quality of service which includes the dimension of "reliability" partially or collectively. Therefore the formulation of the implications of this research emphasizes on efforts in improving payment schemes so that customer satisfaction can increase.

Price is the view of the customer in seeing the price seen from the high and low prices affecting the purchase decision. Price views referring to the price indicator are: 1) Price list; 2) Discounts; 3) Discounts; 4) Period of payment; 5) Price competitiveness and 6) Affordability of prices, can affect the customer in emmuaskan desire. Pandagan price through the price indicator will provide convenience to customers to transact. The better the view of the customer's price will make the customer more comfortable and conscientious in consuming the services provided to him. When the customer's price view meets the standards according to customer expectations, then the customer will be satisfied. Vice versa, if not in accordance with expectations then the customer will be disappointed or not satisfied. Thus it can be expected that there is a relationship between price and customer satisfaction.

The effort to reduce customer satisfaction through price can be done by informing the price list clearly, giving discount to customer according to profile (economic level or employee's family), giving exact discount, bench marking against hospital prices around to see power competitiveness and affordability primarily and the most powerful effect is the provision of a more varied payment period scheme by partnering with financing and insurance institutions.

\section{Suggestions}

\section{Things that need to be improved in pricing}

a. Implemented a better payment period strategy to influence competition.

b. Conducting bench marking to hospitals to continuously evaluate the need to adjust prices due to external forces that affect and change in the product / service.

c. Improves care rooms, beds, mattresses and attractive interior design.

d. Setting the optimum administrative cost rate and elimination of unnecessary patient costs.

e. Improve the quality of product attributes so that it can be used for a long time. f. Bhakti Medicare Hospital, Cicurug, Sukabumi Regency need to adapt and follow the trend in hospital product product.

g. Implemented a better payment period strategy to influence competition.

h. Conducting bench marking to hospitals to continuously evaluate the need to adjust prices due to external forces that affect and change in the product / service.

i. Improves care rooms, beds, mattresses and attractive interior design.

j. Setting the optimum administrative cost rate and elimination of unnecessary patient costs.

$\mathrm{k}$. Improve the quality of product attributes so that it can be used for a long time.

Bhakti Medicare Hospital, Cicurug, Sukabumi Regency need to adapt and follow the trend in hospital product product.

\section{REFERENCES}

[1] Republika online Tuesday, 13 August 2013 | 08:07 WIB Post-Lebaran, Patients Who Treat at the Hospital Skyrocket

[2] Handi Irawan. 2002. 10 Principles of Customer Satisfaction, Jakarta: PT Elex Media Komputindo, Page 2.

[3] Zeithaml, V, A \& Bitner, M, J \& Gremler, D, D 2009. Service Marketing, Issue Five. (Mc Graw Hill: United States of America), Page 130.

[4] P.Baines, C. Fill, and K. Page. Marketing. Newyork: Oxford University Press, 2011, Page. 331-332.

[5] Tjiptono, Fandy, 2007. Marketing strategy. Second edition. (Yogyakarta: Andi, 2007), Page. 151.

[6] Arslan Umar, Rohaizat Bahrun, Inda Sukati, 2015. Sotumer Satisfaction as mediator between proce, trus and brand loyalty: A case study from Malaysia, Universiti Teknologi Malaysia, Journal..

[7] Lily Harkato dad Yurike Venesia. 2015. The Influence of Service Quality And Price Perception Of Customer Satisfaction At Airline Tiger Air Mandala, E-Journal Widya Ekonomika, Volume 1 No. 1 October 2015, ISSN 2338-7807 (Jakarta: Widya Ekonomika,).

[8] Indah Artiningtyas. The Influence of Service Quality, Price Persepso and Trust on Customer Satisfaction (Case Study At Tire Retail Store To Cool Semarang). Journal of Management Faculty of Economics, University of Pandanaran Semarang.

[9] Sugiyono. 2008. Quantitative Educational Research Methods, Qualitative and R \& D Publisher CV Alfabet Bandung Year 